\title{
Influence of substrate types and morphological traits on movement behavior in a toad and newt species
}

\author{
Audrey Trochet ${ }^{\text {Corresp., }}{ }^{1,2}$, Hugo Le Chevalier ${ }^{1,2}{ }^{2}$, Olivier Calvez ${ }^{2}$, Alexandre Ribéron ${ }^{1}$, Romain Bertrand ${ }^{2,3}$, \\ Simon Blanchet ${ }^{1,2}$ \\ ${ }^{1}$ Laboratoire Evolution et Diversité Biologique, Université Paul Sabatier (Toulouse III), Toulouse, France \\ 2 Station d'Ecologie Théorioque et Expérimentale, CNRS, Moulis, France \\ ${ }^{3}$ Center for Biodiversity Theory and Modelling, CNRS, Moulis, France \\ Corresponding Author: Audrey Trochet \\ Email address: audrey.trochet@sete.cnrs.fr
}

Background. Inter-patch movements may lead to genetic mixing, decreasing both inbreeding and population extinction risks, and is hence a crucial aspect of amphibian meta-population dynamics. Traveling through heterogeneous landscapes might be particularly risky for amphibians. Understanding how these species perceive their environment and how they move in heterogeneous habitats is an essential step in explaining metapopulation dynamics and can be important for predicting species' responses to climate change and for conservation policy and management. Methods. Using an experimental approach, the present study focused on the movement behavior (crossing speed and number of stops) on different substrates mimicking landscape components (human-made and natural substrates) in two amphibian species contrasting in locomotion mode: the common toad (Bufo bufo), a hopping and burrowing anuran and the marbled newt (Triturus marmoratus), a walking salamander. We tested the hypothesis that species reaction to substrate nature is dependent on specific ecological requirements or locomotion modes because of morphological and behavioral differences. Results. In both species, substrate type influenced individual crossing speed, with individuals moving faster on soil than on concrete substrate. We also demonstrated that long-legged individuals moved faster than individuals with short legs. In both species, the number of stops was higher in females than in males. In common toads, the number of stops did not vary between substrates tested, whereas in marbled newts the number of stops was higher in cement than in soil substrate. Discussion. We highlighted that concrete substrate (mimicking roads) negatively affect the crossing speed of both studied species, with an effect potentially higher in marbled newts. Our findings corroborate negative effects of such heterogeneous landscapes on movement behavior of two amphibian species, which may have implications for the dynamics of metapopulations. 
1 Influence of substrate types and morphological traits on movement behavior in a toad and

2 newt species

3 Audrey Trochet ${ }^{1,2}$, Hugo Le Chevalier ${ }^{1,2}$, Olivier Calvez ${ }^{2}$, Alexandre Ribéron ${ }^{1}$, Romain

4 Bertrand $^{2,3}$, and Simon Blanchet ${ }^{1,2}$

$5{ }^{1}$ CNRS, ENFA, UMR 5174 EDB (Laboratoire Evolution et Diversité Biologique), Université

6 Paul Sabatier, 118 route de Narbonne, Toulouse F-31062, France

$7 \quad{ }^{2}$ CNRS, Université Paul Sabatier Toulouse III, UMR 5321 SETE (Station d'Ecologie Théorique

8 et Expérimentale), 2 route du CNRS, Moulis F-09200, France

$9{ }^{3}$ CNRS, Université Paul Sabatier Toulouse III, UMR 5321 SETE (Station d'Ecologie Théorique

10 et Expérimentale), Centre for Biodiversity Theory and Modelling, 2 route du CNRS, Moulis F-

1109200 , France

12

13 Corresponding Author:

14 Audrey Trochet ${ }^{1,2}$

15

16 Email address: trochet.audrey@wanadoo.fr

17 


\section{Abstract}

Background. Inter-patch movements may lead to genetic mixing, decreasing both inbreeding and population extinction risks, and is hence a crucial aspect of amphibian meta-population dynamics. Traveling through heterogeneous landscapes might be particularly risky for amphibians. Understanding how these species perceive their environment and how they move in heterogeneous habitats is an essential step in explaining metapopulation dynamics and can be important for predicting species' responses to climate change and for conservation policy and management.

Methods. Using an experimental approach, the present study focused on the movement behavior (crossing speed and number of stops) on different substrates mimicking landscape components (human-made and natural substrates) in two amphibian species contrasting in locomotion mode: the common toad (Bufo bufo), a hopping and burrowing anuran and the marbled newt (Triturus manamoratus), a walking salamander. We tested the hypothesis that species reaction to substrate nature is dependent on specific ecological requirements or locomotion modes because of morphological and behavioral differences.

Results. In both species, substrate type influenced individual crossing speed, with individuals moving faster on soil than on concrete substrate. We also demonstrated that long-legged individuals moved faster than individuals with short legs. In both species, the number of stops was higher in females than in males. In common toads, the number of stops did not vary bermeen substrates tested, whereas in marbled newts the number of stops was higher in cement than in soil substrate. 
40 Discussion. We highlighted that concrete substrate (mimicking roads) negatively affect the 41 crossing speed of both studied species, with an effect potentially higher in marbled newts. Our

42 findings corroborate negative effects of such heterogeneous landscapes on movement behavior

43 of two amphibian species, which may have implications for the dynamics of metapopulations.

44

45 Key words

46

47 Matrix permeability, inter-patch movements, roads, fragmented landscapes, common toads, 48 marbled newts, connectivity, Salamandridae, Bufonidae 
52

53

54

55

56

57

\section{Introduction}

Inter-patch movements are key processes for maintaining gene flow among populations (Kareiva \& Wennergren, 1995; Ronce, 2007) with strong consequences for metapopulation dynamics and population persistence (Clobert et al., 2001; Bowler \& Benton, 2005; Clobert et al., 2012). For decades, the architecture of landscapes has profoundly changed due to human activities. Anthropogenic practices, such as agriculture, urbanization or the expansion of road networks, have led to discontinuities in the habitat matrix: formerly continuous habitats become smaller and more isolated from each other, resulting in the well-known habitat fragmentation pattern (Collinge, 2009; Wilson et al., 2016). Fragmentation and land use change could create inhospitable habitat within the current mobility range of individuals, which may force them to adapt their movement behavior (Arendt, 1988; Andreassen \& Ims, 1998; Kuefler et al., 2010) to ensure sufficient connectivity among populations in spite of these environmental changes. This change in movement behavior may increase the costs associated with mobility, for instance by exposing individuals to higher mortality rate during the transience phase (when crossing roads, for example; Carr, Pope \& Fahrig, 2002). Elucidating how individuals react and adapt their movement patterns in disturbed landscapes might improve our knowledge of metapopulation dynamics across a changing landscape, increase the realism of predictions of species' responses to global change, and support the implementation of pertinent conservation plans.

One third of the amphibian species are currently threatened worldwide, with $43 \%$ of species having declined over the last few decades (Stuart et al., 2004). Due to ecological requirements, pond- and stream-breeding amphibians are exposed to different habitat types (i.e. both terrestrial and aquatic) throughout their life cycle, often in patchy and heterogeneous landscapes (Marsh \& Trenham, 2001). During the terrestrial phase, individual movements are 
75 risky, due to through predator and UV-B exposure (Kats et al., 2000) and desiccation risk

76 (Rothermel \& Luhring, 2005; Pittman et al., 2013; Pittman, Osbourn \& Semlitsch, 2014). Many

77 studies have considered the multiple effects of habitat fragmentation — and their related

78 landscape components - on amphibian populations, both at the individual and population levels

79 (see Cushman, 2006 for a review). In particular, urban areas and human-made infrastructure,

80 such as roads, negatively affect these species in two ways: directly, through fatal collisions with

81 vehicles (Fahrig et al., 1995; Rytwinski \& Fahrig, 2015) and indirectly by fragmenting habitat

82 and subsequent reduction of gene flow and colonization events (deMaynadier \& Hunter, 2000;

83 Mazerolle, 2004; Marsh et al., 2005; Cosentino, Schooley \& Phillips, 2011; Youngquist et al.,

84 2016; Lenhardt et al., 2017). Amphibians are more susceptible to fatal collisions when crossing

85 roads during migration (Glista, DeVault \& DeWoody, 2008) because they often become

86 immobile when facing an approaching vehicle (Mazerolle, Huot \& Gravel, 2005; Bouchard et

87 al., 2009). Also, the mobility of crossing individuals could be affected by the nature of the road's

88 substrate. In this vein, several studies investigated the effects of different substrates on individual

89 movements at the intra-specific level (Ims \& Yoccoz, 1997; Wiens, Schooley \& Weeks, 1997;

90 Wiens, 2001; Stevens et al., 2006; Semlitsch et al., 2012). For instance in Plethodon metcalfi, the

91 individual crossing speed was higher on asphalt than on grass (Semlitsch et al., 2012) with

92 various consequences on mobility success. Some amphibian species can also benefit from

93 anthropogenic landscape elements. For example, Rhinella marina (cane toads) seemed to use

94 roads as dispersal corridors in Australia (Brown et al., 2006). Despite the crucial importance of

95 inter-patch movements in altered landscapes, little is known about the multi-species interactions

96 among individual movements and different substrates (but see Rothermel \& Semlitsch, 2002).

97 Indeed, habitat-species interactions are complex and highly specific (Kolozsvary \& Swihart, 
98 1999; Trochet et al., 2016a). Heterogeneous landscapes and associated landscape parameters

99 could differently alter movement of organisms with strong divergence between species

100 (Rothermel \& Semlitsch, 2002) resulting in contrasting conservation needs and species

101 suitability under global change.

102 The costs associated with inter-patch movement can be high (Van Dyck \& Baguette, 103 2005) and could lead to high selective pressures on mobility and associated phenotypic traits

104 (Bonte et al., 2012). According to this expectation, many studies have focused on the correlation

105 between movement and phenotypic traits. At the intra-specific level, phenotypic differences

106 related to dispersal ability between individuals have been reported. For instance, larger and/or

107 longer individuals are generally expected to be dispersers, because they should benefit from their

108 high levels of competition to disperse farther (Léna et al., 1998). Evidence for a relationship

109 between body size and movement has been described in many taxa (insects: Anholt, 1990;

110 Legrand et al., 2015; mammals: Gundersen, Andreassen \& Ims, 2002; Holekamp \& Sherman, 111 1989; O’Riain, Jarvis \& Faulkes, 1996; reptiles: Léna et al., 1998; birds: Barbraud, Johnson \&

112 Bertault, 2003; Delgado et al., 2010; fishes: Radinger \& Wolter, 2014; amphibians; Ousterhout

$113 \&$ Semlitsch, 2018). For walking and/or hopping animals, selection for efficient displacement

114 might lead to leg elongation. As a result, morphological adaptation to movement can be deduced

115 from estimates of leg length (Moya-Laraño et al., 2008). This correlation between movement and

116 leg length (i.e. hind-limb length, hereafter HLL) has been demonstrated in some species (reptiles:

117 Losos, 1990; spiders: Moya-Laraño et al., 2008; amphibians: Bennett, Garland \& Else, 1989;

118 Choi, Shim \& Ricklefs, 2003; Phillips et al., 2006), but still remains rare. Understanding how amphibians perceive their environment and how they actually move

120 in heterogeneous habitats is an essential step for understanding metapopulation structure, and can 
121 be important for improving the realism of predictive models of species' responses to global

122 change. The present study focused on the movement behavior (crossing speed) on two different

123 substrates mimicking landscape components (a human-made substrate and a natural substrate) in

124 two contrasting amphibian species, the common toad (Bufo bufo), a hopping and burrowing

125 anuran, and the marbled newt (Triturus marmoratus), a walking salamander. Each species has

126 specific ecological requirements: common toads have an explosive breeding season and spend a

127 large proportion of their life on terrestrial habitats (i.e. forests, bushlands, or urban areas)

128 whereas the breeding season of marbled newts is longer, and this species inhabits relatively small

129 well-vegetated ponds surrounded by woodlands (Jehle \& Arntzen, 2000; AmphibaWeb, 2012).

130 Contrary to common toads that generally avoid this kind of habitat type, marbled newts also

131 occur in more open areas like heathens and agricultural landscapes. Common toads and marbled

132 newts can live within the same habitat, such as grassland or woodland, and could therefore face

133 the same environmental pressures during terrestrial movements (Daversa, Muths \& Bosch 2012;

134 Trochet et al., 2017). Also, both the contrasting morphology and modes of locomotion induce

135 different muscular contractions during displacement, leading to different mobility ability

136 between the two species (Smith and Green, 2005) and therefore explain the selection of various

137 habitats encounter during terrestrial phase.

138 Our study aimed at testing the influence of different substrate types on two amphibian

139 species in order to highlight if and how substrates can alter movement in these sympatric species.

140 Considering these species allowed testing the hypothesis that species could react differently to

141 substrate nature, depending on specific ecological requirements, mobility abilities or locomotion

142 modes because of morphological and behavioral differences. Identifying such differences could

143 help improving our understanding about species-specific interactions within a human-made 
144 environment. Consequently, it would be interesting to consider those interactions to improve

145 predictive models of species' responses to climate change and to propose efficient conservation

146 management plans.

147

148 Materials \& Methods

Studied species

The common toad is one of the most widely distributed and abundant anuran species in Europe

(Gasc et al., 1997). Usually, reproduction occurs in February, and large numbers of toads migrate

154

155

156

157

158

159

160

161

162

163

164

165

166

to breeding sites (i.e. large ponds, ditches or lakes with relatively clear water, quite variable in area and depth; AmphibaWeb, 2012) where the males compete for mating. After an explosive breeding season, toads leave ponds and return to terrestrial habitats (Gittins, 1983) where they spend a large proportion of their life. This species occupies various terrestrial habitats over 3-4 $\mathrm{km}$ from the breeding site (Smith and Green, 2005), such as coniferous, mixed and deciduous forests, bushlands, but also urban areas such as gardens and parks (Nollërt and Nollërt, 2003). Common toads hibernate singly or in groups from September to February, on land and occasionally in streams and springs.

The marbled newt is a large-bodied urodele species from Western Europe, found in France, Spain and Portugal (Sillero et al., 2014). The reproduction period is longer than common toads (from the beginning of March until July) and takes place in different aquatic habitats, including well-vegetated ponds, pools, ditches and streams (AmphibiaWeb, 2017). After breeding, adults leave water bodies by walking, and deciduous or mixed woodland, where they 
167 find refuges under dead and rotting wood and other hiding places (Jehle \& Arntzen, 2000).

168 Displacement distances of newts around their breeding sites are shorter than anurans and in the 169 range of several hundred meters (Trochet et al., 2017).

170

Sampling and morphological measurements

172

173 Our work complies with the international animal care guidelines of the Association for the Study

174 of Animal Behaviour, and all required French permits relating to authorization of capture,

175 marking, transport, detention, use and release of protected amphibian species have been obtained

176 (permit nos. 09-2014-14 and 32-2014-07; animal experimentation accreditation $\mathrm{n}^{\circ} \mathrm{A} 09-1$ ) from

177 the DREAL Occitanie (“Direction Régionale de l'Environnement, de l'Aménagement et du

178 Logement"). Ethical approval was included under the protected species handling permit from the

179 DREAL Occitanie. The project was approved by the "Conseil National de la Protection de la

180 Nature" on 14 September 2014 and by the "Conseil Scientifique Régional du Patrimoine Naturel

181 (CSRPN)" of the region Midi-Pyrénées on 14 October 2014.

182 In total, 83 common toads (68 males and 15 non-gravid females) and 46 marbled newts

183 (23 males and 23 non-gravid females) were captured in the south of France at the end of

184 breeding season (for toads: from 13 to 20 March 2015; for newts: from 28 April to 6 May 2015)

185 within and near two different ponds to reduce potential impact on populations (geographical

186 coordinates of pond $143.671781^{\circ} \mathrm{N}, 0.504308^{\circ} \mathrm{E}$ and pond $2: 43.076347^{\circ} \mathrm{N}, 1.351639^{\circ} \mathrm{E}$ ).

187 Individuals were then brought to the lab for experimentation and released between June and July

188 2015. During experiments, animals were housed at the Station d'Ecologie Théorique et

189 Expérimentale (Moulis, France) in same-species groups of 4 to 6 individuals in semi-aquatic 
190 terraria of $60 \times 30 \times 30 \mathrm{~cm}$ at $20^{\circ} \mathrm{C}$. They were fed ad libitum with live mealworms and tubifex

191 worms. For unambiguous identification, all individuals were PIT-tagged (RFID Standards ISO

19211784 \& 11785 type FDX-B, $1.4 \times 8$ mm, 134.2 khz from BIOLOG-ID, France; animal

193 experimentation accreditation $\left.\mathrm{n}^{\circ} \mathrm{A} 09-1\right)$ immediately after capture and before the experiments

194 following the protocol developed in Le Chevalier et al. (2017). We then measured snout-to-vent

195 length (SVL) and hind limb length (HLL) to the nearest $1 \mathrm{~mm}$ and body weight (mass) to the

196 nearest $0.01 \mathrm{~g}$. To limit the effects of stress on behavioral responses, all individuals were kept in

197 captivity for several days without any manipulation until the experimental tests.

198

199

Movement tests

200

201 All tests were performed in June and July 2015, after the breeding season when all individuals

202 were in the terrestrial phase. In order to test the crossing capacities of both species, we made

203 them move along two tracks (200 cm long $\times 10 \mathrm{~cm}$ wide $\times 20 \mathrm{~cm}$ high), each filled with a

204 different substrate: smooth concrete slab (i.e., human-made) or soil (natural). Tracks were not

205 moistened so that the substrate was unfavorable. During the experiments, all individuals were

206 chased down the tracks and forced to move by gently poking their back with a finger after each

207 stop ( 3 seconds between pokes if needed). Only one individual was tested at a time and we

208 recorded the number of stops (stops) and the crossing speed (in cm/sec; including stops) to the

209 nearest $0.1 \mathrm{~s}$ to travel $200 \mathrm{~cm}$ from departure to arrival line. In order to provide reliable estimates

210 of crossing capacity using a repeated-measure design while minimizing stress, every individual

211 was tested three times on each substrate. In toads, tests were randomly spread over two days

212 (three trials on day 1 and three trials on day 2; from the 18 to the 31 March 2015) while newts, 
213 for which we kept animals during a longer period for another experiment not detailed here, tests

214 were randomly performed over $27.9 \pm 8.5$ days (mean $\pm \mathrm{SD}$; from the 28 April to the 2 June

215 2015). Outside of test periods, animals were returned to the semi-aquatic aquaria. Because

216 locomotion in amphibians is influenced by temperature (Herrel \& Bonneaud, 2012; James et al.,

217 2012; Šamajová \& Gvoždík, 2010), all tests were performed in a greenhouse under controlled-

218 temperature conditions (mean $\pm \mathrm{SD}: 25^{\circ} \mathrm{C} \pm 1^{\circ} \mathrm{C}$ ) with light conditions similar to nature.

219 Some individuals $(n=32)$ did not complete the $200 \mathrm{~cm}$ run (stopping completely -3

220 successive pokes without moving - or turning back), these individuals and their replicates were

221 removed from the analyses for statistical reasons. We therefore included 77 toads $(77$ toads $\times 3$

222 replicates $\times 2$ substrates $=462$ tests $)$ and 20 marbled newts $(20$ newts $\times 3$ replicates $\times 2$

223 substrates $=120$ tests) in the analyses.

224

225 Statistical analyses

226

227

Mass and HLL were strongly related to $S V L\left(\mathrm{r}_{s}=0.866, P<0.001\right.$, and $\mathrm{r}_{S}=0.691, P<0.001$,

respectively). To avoid collinearity in our model, we used the scaled mass index $\left(M_{i}\right)$ of condition using the following equation:

$$
M_{i}=M \times\left(S V L_{0} / S V L\right)^{b S M A}
$$

where M and SVL are the body mass and the snout-vent length of the individual, respectively.

$\mathrm{SVL}_{0}$ is the mean SVL of the population, and $b_{\mathrm{SMA}}$ is the standardized major axis slope from the 
237 as response variable, individual as a random factor and $\mathrm{M}_{\mathrm{i}}$, leg, substrate, sex, species and first

238 order interactions between species and other variables as fixed effects. Because the crossing

239 speed was strongly related to the number of stops in both species (Spearman correlations: $T$.

240 marmoratus: $\mathrm{r}_{s}=-0.543, P<0.001 ;$ B. bufo: $\left.\mathrm{r}_{s}=-27, P<0.001\right)$, we also added stops as

241 covariate in our models. We then built a second LMMs using stops as response variable,

242 individual as a random factor and $\mathrm{M}_{\mathrm{i}}$, leg, substrate, sex, species and first order interactions

243 between species and other variables as fixed effects. LMMs were performed using the lme4 R-

244 package (Bates et al., 2017).

Model selection was performed using the Akaike information criteria (AIC; Burnham \&

Anderson, 2002). If several best models were retained $(\Delta \mathrm{AIC}<2)$, we used a model averaging

procedure among all possible models to determine the relative importance of each selected

variable. Two parameters from this averaging procedure were retained to test the importance of

each variable on the crossing speed: the confidence interval of the averaged estimated slope of

the selected term (high effects had confidence intervals that did not include zero) and the relative

which the term appeared). All statistical analyses were performed using R v.3.1.0 (R

Development Core Team, 2014).

\section{Results}

After model selection, the best models explaining variation in crossing speed retained substrates 
259 Crossing speed was significantly lower in marbled newts than in common toads, and both

260 species moved faster on soil than on concrete (Table 1; Fig. 1). Crossing speed was also

261 correlated with morphological traits. Long-legged individuals moved faster than individuals with

262 short legs (Table 1).

263 The variable stops was also influenced by species and substrates, and by sex and the

264 interaction between substrates and species (Table 2). In both species, the number of stops was

265 higher in females than in males. In common toads, stops did not vary between substrate tupes,

266 whereas in marbled newts the number of stops was significantly higher in cement than in soil

267 (Table 2).

268

269

\section{Discussion}

270

271 Our results demonstrated that both species were affected by substrate types, moving significantly

272 slower on a human-made (concrete) than on a natural (soil) substrate. Crossing speed was also

273 related to a mor

274 shorts legs. Then, we revealed that the number of stops to cross $200 \mathrm{~cm}$ was influenced by sexes,

275 substrates and species, which indicates that substrates could differently affect the mobility of two

276 sympatric species living into similar habitats.

277

278 Influence of substrate type on crossing speed

279

280 Inter-patch movement is expected to depend on the nature of the substrate crossed. Some

281 landscape features may be associated with high resistance to movement while others facilitate 
282 movement (low resistance). In a previous study, Stevens et al. (2006) experimentally

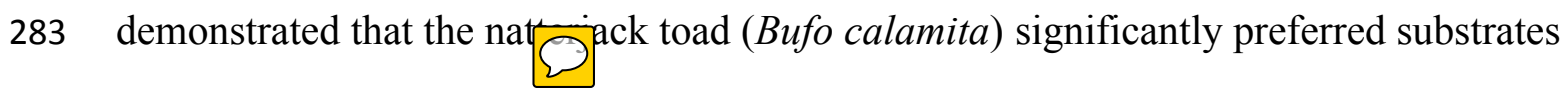

284 mimicking forest and bare than those mimicking agricultural lands. Another similar study

285 revealed that in Plethodon metcalfi, individual crossing speed was higher on asphalt than on

286 grass and soil (Semlitsch et al., 2012) with various consequences on mobility success.

287 In our experiment, the concrete substrate represented linear roads, both in its nature (mixture of

288 cement and gravel) and length ( 2 meters wide road). Roads constitute a very hostile environment

289 for amphibians (dry and warm substrate that could induce a desiccation risk, collisions with

290 vehicles and/or habitat fragmentation; Fahrig et al., 1995; deMaynadier \& Hunter, 2000;

291 Mazerolle, 2004a; Marsh et al., 2005; Cosentino et al., 2011a,b; Youngquist et al., 2016;

292 Lenhardt et al., 2017). According to our hypotheses, our results showed that substrate type

293 influenced the movement behavior of both species. Contrary to previous studies suggesting that

294 terrestrial amphibians moved more quickly and directly through unfavorable areas in which they

295 are physiologically stressed (Semlitsch et al., 2102; Peterman et al., 2014), we revealed that both

296 common toads and marbled newts moved faster (i.e. higher crossing speed) on soil than on

297 concrete (Fig. 1; Table 1). We then suggest that both species could be more exposed to traffic,

298 and suffer more from both desiccation and mortality risks on roads than on soil (Petronilho \&

299 Dias, 2005; Santos et al., 2007; Sillero, 2008; Bouchard et al., 2009; Elzanowski et al., 2009;

300 Matos, Sillero \& Argaña, 2012).

301 In both species, the number of stops was higher in females than in males, independently

302 of substrate type (Table 2). Such differences between sexes may be driven by divergent breeding

303 benefits, which could lead to a trade-off between movement and high energetic costs of

304 reproduction in females, and the well-known sex-biased dispersal (see Trochet et al. 2016b). 
305

306

307

308

309

310

311

312

313

314

315

316

317

318

319

320

321

322

323

324

325

326

327

Indeed, some dies found male-biased dispersal in amphibian species, in anurans as well as in urodela, supposing that females are philopatric in these organisms (Austin et al., 2003; Lampert et al., 2003; Liebgold, Brodie \& Cabe, 2011). In our study, males seem more likely to disperse because they stopped less often than females. As a result, males could also harolower mortality risks induced by collisions with vehicles than females when crossing roads, with may have strong consequences on population dynamics. Our results also demonstrated that the number of stops did not vary between substrates in common toads, while in marbled newts stopped more Q often on cement than on soil (Table 2). This last result shows that marbled newts may be even more at-risk than toads on pavement (and then on roads) because both their crossing speed and their number of stops increased in this substrate type.

In the context of a fragmented landscape, our results corroborate the negative effects of urbanization and human-made infrastructures such as roads on amphibians, leading to an increase in population extinction risk (Fahrig et al., 1995; Carr, Pope \& Fahrig, 2002; Sotiropoulos et al., 2013). Here, we highlight a direct influence of the substrate on the displacement of two amphibian species with divergent ecological requiremgnts and locomotion D modes living within similar habitats. Our findings are relevant for the realism improvement of species dispersal in predictive modeling, notably by informing landsce 9 permeability for species, body size distribution and sex-biased dispersal. They also emphasized the importance of road-crossing structure and landscape management at a small spatial scale for amphibian conservation.

\section{Movement-related traits in both species}


328 According to our expectations, our results showed an influence of a morphological trait (leg) on

329 the crossing speed in both species. Various morphological variables enable organisms to be 330 adapted for ecologically effective movement (Bennett, Garland \& Else, 1989; Losos, 1990; Choi,

331 Shim \& Ricklefs, 2003; Phillips et al., 2006; Moya-Laraño et al., 2008), such as hind limb

332 length. A recent meta-analysis among several anuran species actually demonstrate that jumping

333 performances were strongly correlated to hind limb length after correcting by snout-to-vent

334 length (Gomes et al., 2009). According to this finding, we also demonstrated that movement

335 behavior (defined here as crossing speed) was related to the limb length in both species (see also

336 Bennett, Garland \& Else, 1989; Choi, Shim \& Ricklefs, 2003; Phillips et al., 2006). Indeed, long-

337 legged individuals moved faster than individuals with short legs (Table 1), which corroborates

338 the idea that limb length may be tightly associated with movement behavior adaptations in 339 amphibians. Longer legs could facilitate more rapid or longer-distance displacement (Phillips et

340 al., 2006), as well as generating other advantages such as improved predator evasion and 341 simplifying the negotiation of barriers and obstacles. As a consequence, the mortality risk of

342 longer-legged individuals could be lower than individuals with short legs.

\section{Limitations of the study}

346 Our experimental protocol is easy-to-use and repeatable but, because of its simplicity, may fail to

347 identify all aspects of the complexity of amphibian's terrestrial movements. Indeed, our results

348 highlight the impact of substrate nature of human-made infrastructures on amphibian movements

349 at a small spatial scale, but in order to validate and understand the consequences of such an

350 impact, field studies (using capture-mark-recapture or telemetry monitoring) are needed. Also, 
351 our studies focus on adults, while most dispersal events are likely to be ensured by juveniles in 352 amphibian species (Semlitsch, 2008). Also, it could be very interesting to test the variation of 353 crossing speed in these organisms under several temperature and humidity conditions. Studying 354 terrestrial displacements of amphibian species on different life stages (larvae, juveniles, and 355 adults) and phases of their life cycle (breeding migrations, dispersal events, etc.) would provide a 356 better identification of the impact of human-made infrastructures on the ecology of amphibian 357 communities, and therefore improve the efficiency of management and conservation efforts.

\section{Conclusions}

Inter-patch movement is a multifaceted process, subject to internal and external biotic and abiotic factors. Our findings demonstrate effects of substrates to cross them on the movement behavior in two contrasting amphibian species living within similar habitats. In particular, individuals moved slower on concrete, making them more vulnerable on roads. In both species, we also showed significant relationship between a morphological trait (leg) and crossing speed, suggesting that long-legged amphibians could cross human-made infrastructures faster, which could reduce mortality risk. Comparing the potential influence of various substrates individual movements is essential for explaining and predicting the dynamics of metapopulation living in strongly altered landscapes, which is a prerequisite for developing appropriate conservation management plans.

\section{Funding Statement}


$\Omega$

374 Financial support was provided by a post-doctoral fellow to AT from the Fondation de France.

375 This work was supported by the French Laboratory of Excellence project "TULIP" (ANR-10-

376 LABX-41; ANR-11-IDEX-0002-02) and benefited from both "Investissement d'Avenir" grants

377 managed by Agence Nationale de la Recherche (AnaEE, ANR-11-INBS-0001AnaEE-Services).

378

379 Data Availability

380

381 The raw data has been supplied as a Supplementary File. 


\section{References}

383 AmphibiaWeb 2012 Bufo bufo: Common Toad <http://amphibiaweb.org/species/127>

$384 \quad$ University of California, Berkeley, CA, USA. Accessed Aug 8, 2018.

385 AmphibiaWeb 2017 Triturus marmoratus: Marbled Newt

$386<$ http://amphibiaweb.org/species/4300> University of California, Berkeley, CA, USA.

$387 \quad$ Accessed Aug 8, 2018.

388 Andreassen HP, Ims RA. 1998. The effects of experimental habitat destruction and patch

389 isolation on space use and fitness parameters in female root vole Microtus oeconomus.

390 Journal of Animal Ecology 67:941-52 DOI: 10.1046/j.1365-2656.1998.6760941.x.

391

392

393

Anholt B. 1990. Size-biased dispersal prior to breeding in a damselfly. Oecologia 83:385-387 DOI: $10.1007 / \mathrm{BF} 00317564$.

Arendt WJ. 1988. Range expansion of the cattle egret (Bubulcus ibis) in the Greater Caribbean basin. Colonial Waterbirds 11:252-262.

Austin JD, Davila JA, Lougheed SC, Boag P. 2003. Genetic evidence for female-biased dispersal in the bullfrog, Rana catesbeiana (Ranidae). Molecular Ecology 12:3165-3172 DOI: 10.1046/j.1365-294X.2003.01948.X.

Barbraud C, Johnson AR, Bertault G. 2003. Phenotypic correlates of post-fledging dispersal in a population of greater flamingos: The importance of body condition. Journal of Animal Ecology 72:246-257 DOI: 10.1046/j.1365-2656.2003.00695.x.

Bates D, Maechler M, Bolker B, Walker S. 2017. Lme4: Linear mixed-effects models using S4 classes. R package version 1.1-13. 
403 Bennett AF, Garland T, Else PL. 1989. Individual correlation of morphology, muscle mechanics,

404

405

406

407

408

409

410

411

412

413

414

415

416

417

418

419

420

421

422

423

424

and locomotion in a salamander. American Journal of Physiology 256:R1200-R1208 DOI: 10.1152/ajpregu.1989.256.6.R1200.

Bonte D, Van Dyck H, Bullock JM, Coulon A, Delgado M, Gibbs M, Lehouck V, Matthysen E, Mustin K, Saastamoinen M, Schtickzelle N, Stevens VM, Vandewoestijne S, Baguette M, Barton K, Benton TG, Chaput-Bardy A, Clobert J, Dytham C, Hovestadt T, Meier CM, Palmer SCF, Turlure C, Travis JM. 2012. Costs of dispersal. Biological Reviews 87:290312 DOI: $10.1111 /$ j.1469-185X.2011.00201.x.

Bouchard J, Ford AT, Eigenbrod FE, Fahrig L. 2009. Behavioral responses of northern leopard frogs (Rana pipiens) to roads and traffic: implications for population persistence. Ecology and Society 14:23 DOI: 10.5751/ES-03022-140223.

Bowler D, Benton T. 2005. Causes and consequences of animal dispersal strategies: Relating individual behaviour to spatial dynamics. Biological Reviews 80:205-225 DOI: $\underline{10.1017 / S 1464793104006645 .}$

Brown GP, Phillips BL, Webb JK, Shine R. 2006. Toad on the road: use of roads as dispersal corridors by cane toads (Bufo marinus) at an invasion front in tropical Australia. Biological Conservation 133:88-94 DOI: 10.1016/j.biocon.2006.05.020.

Burnham K, Anderson D. 2002. Model selection and multimodel inference: A practical information-theoretic approach, 2nd ed. New York: Springer Verlag.

Carr L, Pope S, Fahrig L. 2002. Impacts of landscape transformation by roads. In: Gutzwiller KJ, ed. Applying Landscape Ecology in Biological Conservation. New York: Springer Verlag, 225-243. 
425 Choi I, Shim JH, Ricklefs RE. 2003. Morphometric relationships of take-off speed in anuran 426 amphibians. Journal of Experimental Zoology 299:99-102 DOI: 10.1002/jez.a.10293.

427 Clobert J, Baguette M, Benton TG, Bullock JM. 2012. Dispersal ecology and evolution. Oxford: $428 \quad$ Oxford University Press.

429 Clobert J, Danchin E, Dhondt AA, Nichols JD. 2001. Dispersal. Oxford: Oxford University $430 \quad$ Press.

431 Collinge SK. 2009. Ecology of fragmented landscapes. Baltimore: Johns Hopkins University $432 \quad$ Press.

433 Cosentino BJ, Schooley RL, Phillips CA. 2011. Spatial connectivity moderates the effect of 434 predatory fish on salamander metapopulation dynamics. Ecosphere 2:1-14 DOI:

$435 \quad \underline{10.1890 / E S 11-00111.1 . ~}$

436 Cushman, S. 2006. A Effects of habitat loss and fragmentation on amphibians: A review and 437 prospectus. Biological Conservation 128:231-240 DOI: 10.1016/j.biocon.2005.09.031.

438

439

440

441

442

443

444

445

Daversa, DR, Muths E, Bosch J. 2012. Terrestrial Movement Patterns of the Common Toad (Bufo bufo) in Central Spain Reveal Habitat of Conservation Importance. Journal of Herpetology 46:658-664 DOI: 10.1670/11-012.

Delgado M, Penteriani V, Revilla E, Nams VO. 2010. The effect of phenotypic traits and external cues on natal dispersal movements. Journal of Animal Ecology 79:620-632 DOI: 10.1111/j.1365-2656.2009.01655.x.

deMaynadier PG, Hunter ML Jr. 2000. Road effects on amphibian movements in a forested landscape. Natural Areas Journal 20:56-65 
446 Elzanowski A, Ciesiołkiewicz J, Kaczor M, Radwańska J, Urban R. 2009. Amphibian road

447

448

449

450

451

452

453

454

455

456

457

458

459

460

461

462

463

464

465

466

467 mortality in Europe: A meta-analysis with new data from Poland. European Journal of

Wildlife Research 55:33-43 DOI: 10.1007/s10344-008-0211-x.

Fahrig L, Pedlar JH, Pope SE, Taylor PD, Wegner JF. 1995. Effect of road traffic on amphibian density. Biological Conservation 73:177-182 DOI: 10.1016/0006-3207(94)00102-V.

Gasc JP, Cabela A, Crnobrnja-Isailovic J, Dolmen D, Grossenbacher K, Haffner P, Lescure J, Martens H, Martinez-Rica JP, Maurin H, Oliveira ME, Sofianidou TS, Veith M, Zuiderwijk A. 1997. Atlas of Amphibians and Reptiles in Europe. Paris: Muséum National d'Histoire Naturelle.

Gittins SP. 1983. The breeding migration of the Common Toad (Bufo bufo) to a pond in midWales. Journal of Zoology 199:555-562

Glista DJ, DeVault TL, DeWoody JA. 2008. Vertebrate road mortality predominantly impacts amphibians. Herpetological Conservation and Biology 3:77-87.

Gomes FR, Rezende EL, Grizante MB, Navas CA. 2009. The evolution of jumping performance in anurans: Morphological correlates and ecological implications. Journal of Evolutionary Biology 22:1088-1097 DOI: 10.1111/j.1420-9101.2009.01718.x.

Gundersen G, Andreassen HP, Ims RA. 2002. Individual and population-level determinants of immigration success on local habitat patches: an experimental approach. Ecology Letters 5:294-301 DOI: $10.1046 / \mathrm{j} .1461-0248.2002 .00320 . x$.

Herrel A, Bonneaud C. 2012. Temperature dependence of locomotor performance in the tropical clawed frog, Xenopus tropicalis. Journal of Experimental Biology 215:2465-2470 DOI: 10.1242/jeb.069765. 
468 Holekamp K, Sherman P. 1989. Why male ground squirrels disperse. American Scientist 77:232$469 \quad 239$

470 Ims RA, Yoccoz NG. 1997. Studying transfer processes in metapopulations: emigration, 471 migration, and colonization. In: Hanski IA, Gilpin ME, eds. Metapopulation Biology: 472 Ecology, Genetics, and Evolution. London: Academic Press, 247-265.

473 James RS, Tallis J, Herrel A, Bonneaud C. 2012. Warmer is better: Thermal sensitivity of both 474 maximal and sustained power output in the iliotibialis muscle isolated from adult Xenopus tropicalis. Journal of Experimental Biology 215:552-558 DOI: 10.1242/jeb.063396.

476

477

478

479

480

481

482

483

484

485

486

487

488

489

Jehle R, Arntzen JW. 2000. Post-breeding migrations of newts (Triturus cristatus and T. marmoratus) with contrasting ecological requirements. Journal of Zoology 251:297-306 DOI: $\underline{10.1111 / \mathrm{j} .1469-7998.2000 . t b 01080 . x}$.

Kareiva P, Wennergren U. 1995. Connecting landscape patterns to ecosystem and population processes. Nature 373:299-302 DOI: 10.1038/373299a0.

Kats LB, Kiesecker JM, Chivers DP, Blaustein AR. 2000. Effects of UV-B on antipredator behavior in three species of amphibians. Ethology 106:921-32 DOI: $\underline{10.1046 / j .1439-}$ $\underline{0310.2000 .00608 . x}$.

Kolozsvary MB, Swihart RK. 1999. Habitat fragmentation and the distribution of amphibians: patch and landscape correlates in farmland. Canadian Journal of Zoology 77:1288-1299 DOI: $\underline{10.1139 / \mathrm{z} 99-102}$.

Kuefler D, Hudgens B, Haddad NM, Morris WF, Thurgate N. 2010. The conflicting role of matrix habitats as conduits and barriers for dispersal. Ecology 91:944-50 DOI: 10.1890/09$\underline{0614.1}$. 
490 Lampert KP, Rand AS, Mueller UG, Ryan MJ. 2003. Fine-scale genetic pattern and evidence for 491 sex-biased dispersal in the túngara frog, Physalaemus pustulosus. Molecular Ecology 12:3325-3334 DOI: 10.1046/j.1365-294X.2003.02016.x.

493

494

495

496

497

498

499

500

501

502

503

504

505

506

507

508

509

510

511

Le Chevalier H, Calvez O, Martinez-Silvestre A, Picard D, Guérin S, Isselin-Nondedeu F, Ribéron A, Trochet A. 2017. Marking techniques in the Marbled Newt (Triturus marmoratus): PIT-Tag and tracking device implant protocols. Acta Herpetologica 12:7988 DOI: $10.13128 /$ Acta_Herpetol-19158.

Legrand D, Trochet A, Moulherat S, Calvez O, Stevens VM, Ducatez S, Clobert J, Baguette M. 2015. Ranking the ecological causes of dispersal in a butterfly. Ecography 38:822-831 DOI: $\underline{10.1111 / \text { ecog.01283. }}$.

Léna JP, Clobert J, de Fraipont M, Lecomte J, Guyot G. 1998. The relative influence of density and kinship on dispersal in the common lizard. Behavioral Ecology 9:500-507 DOI: 10.1093/beheco/9.5.500.

Lenhardt PP, Brühl CA, Leeb C, Theissinger K. 2017. Amphibian population genetics in agricultural landscapes: does viniculture drive the population structuring of the European common frog (Rana temporaria)? PeerJ 5:e3520 DOI: 10.7717/peerj.3520.

Liebgold EB, Brodie ED $3^{\text {rd }}$, Cabe PR. 2011. Female philopatry and male-biased dispersal in a direct-developing salamander, Plethodon cinereus. Miolecular Ecology 20:249-257 DOI: 10.1111/j.1365-294X.2010.04946.x.

Losos JB. 1990. Ecomorphology, performance capability, and scaling of West Indian Anolis lizards: an evolutionary analysis. Ecological Monographs 60:369-388 DOI: $\underline{10.2307 / 1943062 .}$ 
512 Marsh DM, Milam GS, Gorham N, Beckham NG. 2005. Forest roads as partial barriers to

513 terrestrial salamander movement. Conservation Biology 19:2004-2008 DOI:

$514 \quad \underline{10.1111 / \mathrm{j} .1523-1739.2005 .00238 . x}$.

515 Marsh DM, Trenham PC. 2001. Metapopulation dynamics and amphibian conservation.

516 Conservation Biology 15:40-49. DOI: 10.1111/j.1523-1739.2001.00129.x.

517 Matos C, Sillero N, Argaña E. 2012. Spatial analysis of amphibian road mortality levels in 518 northern Portugal country roads. Amphibia-Reptilia 33:469-483 DOI: $10.1163 / 15685381-$ $519 \quad \underline{00002850}$.

520 Mazerolle MJ. 2004. Amphibian road mortality in response to nightly variations in traffic 521 intensity. Herpetologica 60:45-53 DOI: $\underline{10.1655 / 02-109}$.

522 Mazerolle MJ, Huot M, Gravel M. 2005. Behavior of amphibians on the road in response to car 523 traffic. Herpetologica 61:380-388 DOI: $\underline{\text { 10.1655/04-79.1. }}$.

524 Moya-Laraño J, Macías-Ordóñez R, Blanckenhorn WU, Fernández-Montraveta C. 2008. 525 Analysing body condition: Mass, volume or density? Journal of Animal Ecology 77:1099-

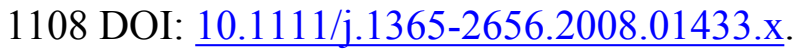

527

528

529 530

531

532

533

Nollërt A, Nollërt C. 2003. Guide des amphibiens d'Europe : Biologie, identification, répartition. Lonay:Delachaux et Niestlé.

O’Riain M, Jarvis J, Faulkes C. 1996. A dispersive morph in the naked mole-rat. Nature 380:619-621 DOI: $10.1038 / 380619 \mathrm{a} 0$.

Ousterhout BH, Semlitsch RD. 2018. Effects of conditionally expressed phenotypes and environment on amphibian dispersal in nature. Oikos 127:1142-1151 DOI: $\underline{10.1111 / \text { oik.05276. }}$ 
534 Peig J, Green AJ. 2009. New perspectives for estimating body condition from mass/length data:

535 the scaled mass index as an alternative method. Oikos 118:1883-1891 DOI:

$536 \quad \underline{10.1111 / \mathrm{j} .1600-0706.2009 .17643 . x .}$

537 Peterman WE, Connette GM, Semlitsch RD, Eggert LS. 2014. Ecological resistance surfaces 538 predict fine scale genetic differentiation in a terrestrial woodland salamander. Molecular $539 \quad$ Ecology 23:2402-2413 DOI: 10.1111/mec.12747.

540 Petronilho JMS, Dias CMM. 2005. Impact of two forest roads upon wildlife after a road 541 pavement change in a coastal area in the center of Portugal. Wildlife Biology in Practice $542 \quad 1: 128-139$.

543 Phillips BL, Brown GP, Webb JK, Shine R. 2006. Invasion and the evolution of speed in toads. $544 \quad$ Nature 439:803 DOI: $\underline{10.1038 / 439803 a .}$

545 Pittman SE, Osbourn MS, Drake DL, Semlitsch RD. 2013. Predation of juvenile ringed

546 salamanders (Ambystoma annulatum) during initial movement out of ponds.

$547 \quad$ Herpetological Conservation and Biology 8:681-687.

548 Pittman SE, Osbourn MS, Semlitsch RD. 2014. Movement ecology of amphibians: a missing 549 component for understanding population declines. Biological Conservation 169:44-53 550 DOI: $10.1016 /$ j.biocon.2013.10.020.

551 R Development Core Team. 2014. R: A language and environment for statistical computing. 552 Vienna: The R Foundation for Statistical Computing.

553 Radinger J, Wolter C. 2014. Patterns and predictors of fish dispersal in rivers. Fish and Fisheries 15:456-473. DOI: $\underline{\text { http://dx.doi.org/10.1111/faf.12028 }}$ 
555 Ronce O. 2007. How does it feel to be like a rolling stone? Ten questions about dispersal

556 evolution. Annual Review of Ecology, Evolution, and Systematics 38:231-253 DOI:

$557 \quad \underline{10.1146 / \text { annurev.ecolsys.38.091206.095611. }}$.

558 Rothermel BB, Luhring TM. 2005. Burrow availability and desiccation risk of mole salamanders

559 (Ambystoma talpoideum) in harvested versus unharvested forest stands. Journal of

560 Herpetology 39:619-626 DOI: 10.1670/251-04A.1.

561 Rothermel BB, Semlitsch RD. 2002. An experimental investigation of landscape resistance of

562 forest versus old-field habitats to emigrating juvenile amphibians. Conservation Biology

$563 \quad 16: 1324-1332$ DOI: $10.1046 / \mathrm{j} .1523-1739.2002 .01085 . \mathrm{x}$

564 Rytwinski T, Fahrig L. 2015. The impacts of roads and traffic on terrestrial animal populations.

565 In: van der Ree R, Smith DJ, Grilo C, eds. Handbook road ecology. Chichester, West

566 Sussex: John Wiley \& Sons, Inc, 237-246.

567 Šamajová P, Gvoždík L. 2010. Inaccurate or disparate temperature cues? Seasonal acclimation of 568 terrestrial and aquatic locomotor capacity in newts. Functional Ecology 24:1023-1030

569 DOI: $10.1111 / \mathrm{j} .1365-2435.2010 .01720 . x$.

570 Santos X, Llorente GA, Montori A, Carretero MA, Franch M, Garriga N, Richter-Boix A. 2007.

571 Evaluating factors affecting amphibian mortality on roads: The case of the Common Toad

572 Bufo bufo, near a breeding place. Animal Biodiversity and Conservation 1:97-104.

573 Semlitsch RD, Ecrement S, Fuller A, Hammer K, Howard J, Krager C, Mozelzy J, Ogle J,

574 Shipman N, Speier J, Walker M, Walkers B. 2012. Natural and anthropogenic substrates

575 affect movement behavior of the Southern Graycheek Salamander (Plethodon metcalfi).

576 Canadian Journal of Zoology 90:1128-1135 DOI: 10.1139/z2012-079. 
577 Semlitsch RD. 2008. Differentiating migration and dispersal processes for pond-breeding

578 amphibians. The Journal of Wildlife Management 72:260-267.

579 Sillero N, Campos J, Bonardi A, Corti C, Creemers R, Crochet PA, Crnobrnja Isailović J, Denoël

580 M, Ficetola GF, Gonçalves J, Kuzmin S, Lymberakis P, de Pous P, Rodrigez A, Sindaco R,

581 Speybroeck J, Toxopeus B, Vieites DR, Vences M. 2014. Updated distribution and

582 biogeography of amphibians and reptiles of Europe. Amphibia-Reptilia 35:1-31 DOI:

$583 \quad \underline{10.1163 / 15685381-00002935 .}$.

584 Sillero N. 2008. Amphibian mortality levels on Spanish country roads: Descriptive and spatial

585 analysis. Amphibia-Reptilia 29:337-347 DOI: $\underline{10.1163 / 156853808785112066}$.

586 Smith MA, Green DM. 2005. Dispersal and the metapopulation paradigm in amphibian ecology

587 and conservation: are all amphibian populations metapopulations? Ecography 28:110-128

588 DOI: $10.1111 /$ j.0906-7590.2005.04042.x.

589 Sotiropoulos K, Eleftherakos K, Tsaparis D, Kasapidis P, Giokas S, Legakis A, Kotoulas G

590 2013. Fine scale spatial genetic structure of two syntopic newts across a network of ponds:

591 Implications for conservation. Conservation Genetics 14:385-400 DOI: 10.1007/s10592-

$592 \quad \underline{013-0452-4 .}$

593 Stevens VM, Leboulengé E, Wesselingh RA, Baguette M. 2006. Quantifying functional

594 connectivity: Experimental assessment of boundary permeability for the Natterjack toad

595 Bufo calamita. Oecologia 150:161-171 DOI: 10.1007/s00442-006-0500-6.

596 Stuart SN, Chanson JS, Cox NA, Young BE, Rodrigues ASL, Fischman DL, Waller RW. 2004.

597 Status and trends of amphibian declines and extinctions worldwide. Science 306:1783-

$598 \quad 1786$ DOI: $10.1126 /$ science.1103538. 
599 Trochet A, Dechartre J, Le Chevalier H, Baillat B, Calvez O, Blanchet S, Riberon A. 2016 a. 600 Effects of habitat and fragmented-landscape parameters on amphibian distribution at a 601 large spatial scale. The Herpetological Journal 26:73.

602 Trochet A, Courtois E, Stevens VM, Baguette M, Chaine A, Schmeller DS, Clobert J. 2016 b. 603 Evolution of sex-biased dispersal. The Quarterly Review of Biology 91:297-320 DOI: $604 \quad \underline{10.1086 / 688097 .}$

605 Trochet A, Le Chevalier H, Calvez O, Barthe L, Isselin-Nondedeu F, Picard D, Debelgarric M, 606 Pégourié N, Rocher R, Ribéron A. 2017. Post-breeding movement correlated with 607 morphology in the marbled newt in forest and agricultural lands: a comparative radio608 tracking study. Herpetologica 73:1-9 DOI: 10.1655/Herpetologica-D-15-00072

609

610

611

612

613

614

615

616

617

618

619

Van Dyck H, Baguette M. 2005. Dispersal behaviour in fragmented landscapes: Routine or special movements? Basic and Applied Ecology 6:535-545 DOI: 10.1016/j.baae.2005.03.005.

Wiens JA, Schooley RL, Weeks RD. 1997. Patchy landscapes and animal movements: Do beetles percolate? Oikos 78:257-264.

Wiens JA. 2001. The landscape context of dispersal. In: Clobert J, Danchin E, Dhondt AA, Nichols JD, eds. Dispersal. Oxford: Oxford University Press, 96-109.

Wilson MC, Chen XY, Corlett RT, Didham RK, Ding P, Holt RD, Holyoak M, Hu G, Hugues AC, Jiang L, Laurance WF, Liu J, Pimm SL, Robinson SK, Russo SE, Si X, Wilcove DS, Wu J, Yu M. 2016. Habitat fragmentation and biodiversity conservation: key findings and future challenges. Landscape Ecology 31:219-227. DOI: 10.1007/s10980-015-0322-1. 
620 Youngquist MB, Boone MD. 2014. Movement of amphibians through agricultural landscapes:

621 The role of habitat on edge permeability. Biological Conservation 175:148-155 DOI:

$622 \quad$ 10.1016/j.biocon.2014.04.028.

623 Youngquist MB, Inoue K, Berg DJ, Boone MD. 2016. Effects of land use on population presence

624 and genetic structure of an amphibian in an agricultural landscape. Landscape Ecology

625 32:147-162 DOI: $\underline{10.1007 / \mathrm{s} 10980-016-0438-\mathrm{y}}$.

626 


\section{Figure caption}

628

629 Figure 1. Mean crossing speed (in $\mathrm{cm} / \mathrm{s}$ ) on concrete and soil substrates in (a) the common toad

630 and (b) the marbled newt. Crossing speed differed significantly between both substrates in toads

631 (Wilcoxon rank-sum test: $P=0.0101$ ) and in newts (Wilcoxon rank-sum test: $P<0.001$ ). Error

632 bars represents standard error.

633 


\section{Figure 1}

Mean crossing speed (in cm/s) on concrete and soil substrates in (a) the common toad and (b) the marbled newt.

Crossing speed differed significantly between both substrates in toads (Wilcoxon rank-sum test: $P=0.0101$ ) and in newts (Wilcoxon rank-sum test: $P<0.001$ ). Error bars represents standard error.

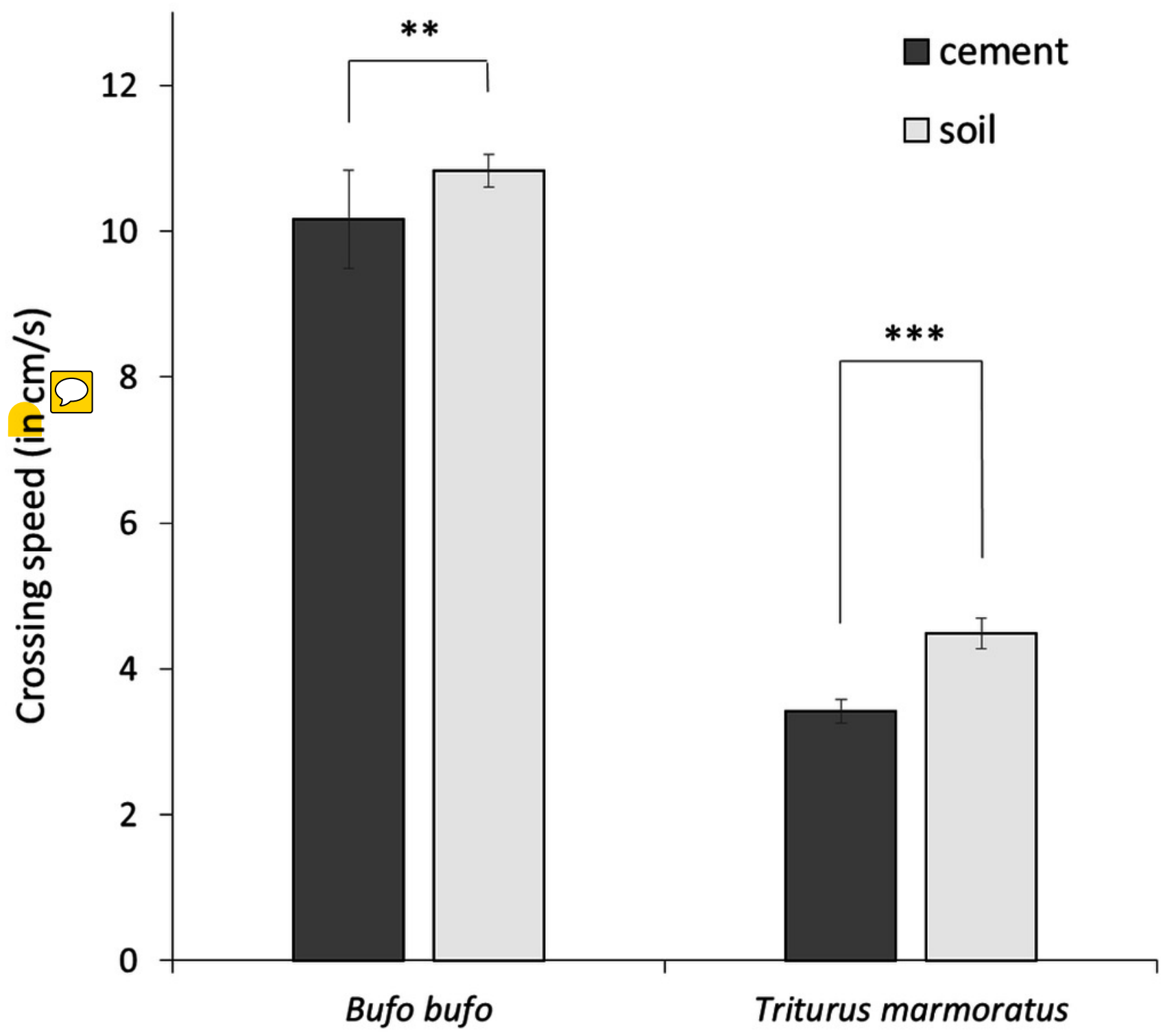




\section{Table $\mathbf{1}$ (on next page)}

Summary of the averaged linear mixed-effects model showing the influence of significant variables on the crossing speed (in $\mathrm{cm} / \mathrm{s}$ ) for the studied species the marbled newt (Triturus marmoratus; $\mathrm{N}=20$ ) and the common toad (Bufo bufo; $\mathrm{N}=$

leg: relative hind-limb length. stops: number of stops. $* * *$ : $<<0.001,{ }^{* *}: \mathrm{P}<0.01$. Weight: relative Akaike weight of the top-ranked models $(\triangle A I C<2)$ in which the term appeared. 
1 Table 1. Summary of the averaged linear mixed-effects model showing the influence of

2 significant variables on the crossing speed (in $\mathrm{cm} / \mathrm{s}$ ) for the studied species the marbled newt

3 (Triturus marmoratus; $\mathrm{N}=20$ ) and the common toad (Bufo bufo; $\mathrm{N}=77$ ). leg: relative hind-limb

4 length. stops: number of stops. ${ }^{* * *}: \mathrm{P}<0.001,{ }^{*}: \mathrm{P}<0.01$. Weight: relative Akaike weight of

5 the top-ranked models $(\triangle \mathrm{AIC}<2)$ in which the term appeared.

\begin{tabular}{|l|c|c|c|c|c|}
\hline & Estimate & \multicolumn{2}{|c|}{$P$} & $95 \%$ CI of estimate & Weight \\
\hline (Intercept) & 2.2793 & $<0.001$ & $* * *$ & $(2.2153 ; 2.3433)$ & \\
\hline Substrate (soil) & 0.0722 & $<0.001$ & $* * *$ & $(0.0378 ; 0.1067)$ & 1.00 \\
\hline Species (Triturus marmoratus) & -1.0940 & $<0.001$ & $* * *$ & $(-1.3533 ;-0.8347)$ & 1.00 \\
\hline leg & 0.0998 & 0.0045 & $* *$ & $(0.0309 ; 0.1687)$ & 0.62 \\
\hline stops & -0.2526 & $<0.001$ & $* * *$ & $(-0.2754 ;-0.2298)$ & 1.00 \\
\hline
\end{tabular}

6 


\section{Table 2 (on next page)}

Summary of the best linear mixed-effect model showing the influence of significant variables on the number of stops to travel $200 \mathrm{~cm}$ during the experimental test for the marbled newt (Triturus marmoratus; $\mathrm{N}=20$ ) and the common toad (Bufo bufo

$* * *: \mathrm{P}<0.001, * *: \mathrm{P}<0.01$ 
1 Table 2. Summary of the best linear mixed-effect model showing the influence of significant

2 variables on the number of stops to travel $200 \mathrm{~cm}$ during the experimental test for the marbled

3 newt (Triturus marmoratus; $\mathrm{N}=20$ ) and the common toad (Bufo bufo; $\mathrm{N}=77)$. ***: $\mathrm{P}<0.001$, $4 \quad * *: \mathrm{P}<0.01$

\begin{tabular}{|l|c|c|c|}
\hline & Estimate & \multicolumn{2}{|c|}{$P$} \\
\hline (Intercept) & 0.7227 & $<0.001$ & $* * *$ \\
\hline Substrate (soil) & -0.1212 & 0.0744 & \\
\hline Species (Triturus marmoratus) & -0.9422 & $<0.001$ & $* * *$ \\
\hline Sex (male) & -0.5453 & 0.0009 & $* *$ \\
\hline Substrate (soil) * Species (Triturus marmoratus) & -0.3937 & 0.0086 & $* *$ \\
\hline
\end{tabular}

